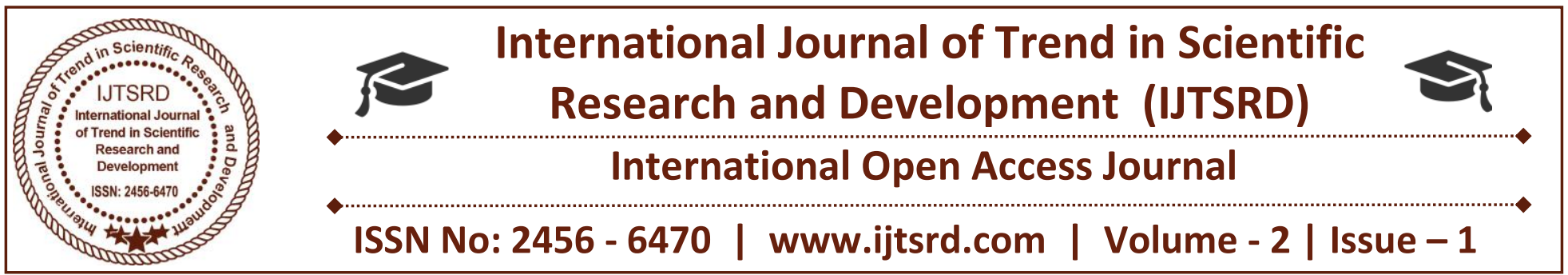

\title{
A Study on Customer Attitude towards Mobile Banking with Special Reference to Erode District
}

\author{
Mr. M. Mohanraj \\ Ph.D Research Scholar [Management], \\ K.S.R College of Arts and Science (Autonomous), \\ Tiruchengode, Tamil Nadu, India
}

\section{ABSTRACT}

Mobile banking plays major roles in the ongoing scenario, based on the up gradation of the technology customer of the banks have started using the banking services through the use of mobile phones. Know-adays mobile phones have become the basic need of every one which helps the consumers to make various kinds of activities. The activities that are done with the help of mobile banking are online transfer of money, ticket reservation, transfer of funds, etc,. Consumers attitude towards mobile banking service is base on the expectation of the consumers like communication has to be properly informed, the transaction process ha $\mathrm{s}$ to be with limited duration, need for interaction, ease to use, etc. Customer attitude has been varying frequently based the changes in technology in banking system. Banking service of consumers has been effective with the help of mobile phones. Mobile Banking has been efficiently use by the customers in order to save their time, money and effort. The sampling size of the research is 200.The statistical tools used in the research are percentage analysis, chi-square, Anova. The main aim of the study is to find customer attitude towards mobile baking and their change of behavior with mobile banking services.

Keywords: Mobile Banking, Customer Attitude, Mobile Phone, technology, consumer behavior.

\author{
Dr. A. T. Jaganathan \\ M.B.A., M.Phil., Ph.D., Head and Department of \\ Business Administration, K.S.R College of Arts and \\ Science (Autonomous), Tiruchengode, Tamil Nadu
}

\section{INTRODUCTION}

Banking in India has been originated in the last decay of 18th century. The first banks are The General Bank of India, which was started in the year 1786 and Bank of Hindustan which was started in the year of 1790 . The oldest bank of India was the State Bank of India which was started in the year 1806.

Mobile banking has changed the traditional way of banking system that allows customers to do the banking services like making deposits, withdraw, send, receive and transfer funds from the mobile account with the help of mobile device. Mobile banking offers various types of information for the customers like

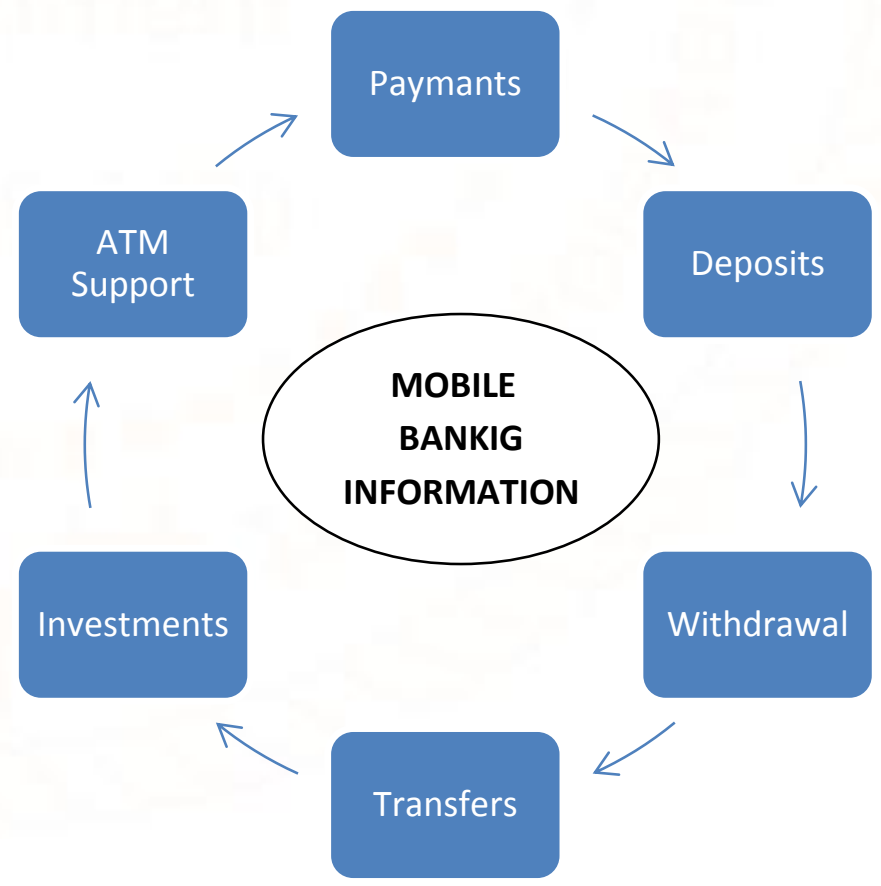


Nowadays consumers of banking has changed their attitude, that they don't want to stand in the bank queues, no need of PC and laptop with the internet connection just with the help of mobile phone all the activities are done with mobile banking system. Mobile banking has been effectively used by all consumers because they don't want wait for others, they can transfer their amount at any time, they can carry mobiles any without any trouble.

Technology has been perfectly used by the banking system, where updations of all the activities have been implemented in banking system. Mobile Banking has helped the banks to improve the quality of services to the customers and it has created the customer relationship management. Through Mobile banking the banks can easily contact the group of customer who are more valuable to the banks. Communication of the banks with the customers helps the bank to sell the financial products.

\section{Key features of mobile banking are}

\# Check the account balances and various information of our account

Customers can view their last 30 days transaction from their history

Transfer of funds from accounts

Balance availability

View the Payment of interest by the banks of various types of accounts

Processing of cheque details

BPAY payments

Purchases that are made with credit card etc.

\section{IMPORTANCE AND NEED OF THE STUDY:}

Mobile banking makes the change in the traditional processing of the Bank works. Customers of the bank moved according to the technology because of their busy schedule of their work. During non-availability of the banking service in holidays they are moving towards the internet services or other outlets to transfer the amount for their purpose, Where the mobile banking helps them to transfer and do all the activities in the same place without moving anywhere. Based on the attitude of the customer there is a change in the behavior banking process with the help of mobile banking which is more comfortable. Banks that are started to develop their activities with the help of mobile banking which is effectively used by the customers.

\section{OBJECTIVES OF THE STUDY}

\section{Primary objective:}

To analyze the factors influencing the customer attitude towards Mobile Banking in Erode District.

\section{Secondary objective:}

$>$ To determine the customer mobile banking behavior.

$>$ To determine the customer expected services in banks.

To analyze the effectiveness of advertisement and promotional activities.

$>$ To observe the overall customer satisfaction on mobile banking.

\section{STATEMENT OF THE PROBLEM}

Banks that is proving the various services for the customer's in order to retain them, based on that the expectation of the customer has to be found by the banks to make their services better. The attitude of the customers is varying form period to period based on the up gradation of the technology. Mobile Banking that helps the customer to make all the activities of the customer to easily done with in a fraction of a second without waiting for anyone, at the same time the banks have to be dynamic in their technology to satisfy the customers.

\section{RESEARCH METHODOLOGY}

It is the science which dealing with principles of procedure in research and study. A detailed survey of customers was carried out to find out their preferences towards Srinivasa Corporation the details of the methodology are stated below.

\section{RESEARCH DESIGN}

Research design is the arrangement of conditions for collection and analysis of data in a manner that aims to combine relevance to the research purpose with economy in procedure.

\section{DESCRIPTIVE RESEARCH DESIGN}

This study aims at describing the nature of respondent's attitude towards Mobile Banking in Erode district. Therefore, this research is can be called as descriptive research. Descriptive research includes surveys and fact finding enquires of different kinds. 
The major purpose of descriptive research is description of the state of affairs as it exists at present.

\section{DATA COLLECTION}

There are two types of data collections.

$>$ Primary data collection

$>$ Secondary data collection

\section{Primary data}

Primary data is first had information it was collected from the respondent by using a structural questionnaire. The researcher has got the primary data through survey method.

\section{Secondary data}

The secondary data was collected through the secondary sources like company records, company websites, magazine, and Newspaper.

\section{SAMPLING METHOD}

Simple Random sampling refers to the collection of information from members of the population who are available to provide it. Random sampling is a probability method.

\section{Sample Unit}

Total sample unit is 150

\section{STATISTICAL TOOLS}

\section{PERCENTAGE ANALYSIS}

Percentage analysis is the method to represent raw streams of data as a percentage (a part in 100 percent) for better understanding of collected data.

Number of respondent

Percentage analysis $=\ldots \ldots \ldots \ldots \ldots \ldots \ldots \ldots \ldots . . \ldots 100$

Total number of respondents

\section{CHI-SQUARE}

Chi-square is a statistical test commonly used to compare observed data with data we would expect to obtain according to a specific hypothesis.

This can be calculated using the formula

$$
\chi^{2}=\sum \frac{(O-E)^{2}}{E}
$$

Where

$\mathrm{O}=$ Observed frequency.

$\mathrm{E}=$ Expected frequency

\section{REVIEW OF LITERATURE}

A. Palani, P. Y. (2012) in his article" A Study On Customer Perception Towards Mobile Banking In Indian Overseas Bank Chennai" his research , carried out to confirm the model of mobile banking. The causes were identified and researched through correcting the causative factors so that mobile banking can be used by more people. This will help the banking operations to be more cost effective. The research is focused on what are the customer's perceptions about mobile banking offered by Indian Overseas Bank and what are the drivers that drive consumers. He found that still the users face many problems right from the telecom operator to banks, the handset to software application support for using services.

Amola bhatt, S. B. (2016) in his article"Factors Affecting Customer's Adoption of Mobile Banking Services. Journal of Internet Banking and Commerce" he says demographic, attitudinal, and behavioural characteristics of mobile bank users were examined. The infrastructural facility of updated user friendly technology and its availability was found to be the most important factor that motivated consumers' attitudes. This study identified two additional factors i.e. infrastructural facility and customer service relevant to mobile banking that were absent in previous researches.

Chandran, R. (2014) in his article " Pros and cons of Mobile banking. International Journal of Scientific and Research Publications" he says that Over the years, banking has transcended from a traditional brick-and mortar model of customers queuing for services in the banks to modern day banking where banks can be reached at any point for their services. It is well recognized that mobile phones have immense potential of conducting financial transactions thus leading the financial growth with lot of convenience and much reduced cost. For inclusive growth, the benefits of mobile banking should reach to the common man at the remotest locations in the country.

Chuchuen, C. (2016) in his article "The Perception of Mobile Banking Adoption: The Study of Behavioral, Security, and Trust in Thailand. International Journal of Social Science and Humanity" he says there are many factors that relate in M-banking adoption process. This paper demonstrates a conceptual model and propositions for identifying Thai adopter factors 
International Journal of Trend in Scientific Research and Development (IJTSRD) ISSN: 2456-6470 of M-banking adoption for improving the M-banking adoption process especially in term of M-banking satisfaction showed that any customers have high expectations toward M-banking.

providers Finally, the relationship between M-banking intention and M-banking adoption which refers to

\section{ANALYSIS AND DISCUSSION}

\section{PERCENTAGE ANALYSIS}

TABLE-I

\begin{tabular}{|c|c|c|c|}
\hline \multicolumn{2}{|l|}{ CHARACTERISTICS } & FREQUENCY & PERCENTA GE \\
\hline \multirow[t]{3}{*}{ Gender } & Male & 50 & 33.3 \\
\hline & Female & 100 & 66.7 \\
\hline & Total & 150 & 100.0 \\
\hline \multirow[t]{4}{*}{ Age } & Below 25 & 35 & 23.3 \\
\hline & $25-35$ & 68 & 45.3 \\
\hline & Above 35 & 47 & 31.3 \\
\hline & Total & 150 & 100.0 \\
\hline \multirow{6}{*}{$\begin{array}{l}\text { Educational } \\
\text { Qualification }\end{array}$} & Below SSLC & 14 & 9.3 \\
\hline & Higher Secondary & 29 & 19.3 \\
\hline & Under graduate & 56 & 37.3 \\
\hline & Post graduate & 22 & 14.7 \\
\hline & Above post graduate & 29 & 19.3 \\
\hline & Total & 150 & 100.0 \\
\hline \multirow[t]{6}{*}{ Occupation } & Govt employee & 20 & 13.3 \\
\hline & Private employee & 36 & 24.0 \\
\hline & Business & 55 & 36.7 \\
\hline & Labor & 19 & 12.7 \\
\hline & Student & 20 & 13.3 \\
\hline & Total & 150 & 100.0 \\
\hline \multirow[t]{4}{*}{ Income } & Below 1,00,000 & 38 & 25.3 \\
\hline & $1,00,000-3,00,000$ & 76 & 50.7 \\
\hline & Above $3,00,000$ & 36 & 24.0 \\
\hline & Total & 150 & 100.0 \\
\hline \multirow[t]{4}{*}{ Transfer of amount } & Below 500 & 22 & 14.7 \\
\hline & $500-1000$ & 68 & 45.3 \\
\hline & Above 1000 & 60 & 40.0 \\
\hline & Total & 150 & 100.0 \\
\hline \multirow{6}{*}{$\begin{array}{l}\text { Frequency of Mobile } \\
\text { Banking }\end{array}$} & Occasionally & 14 & 9.3 \\
\hline & Periodically & 63 & 42.0 \\
\hline & Monthly once & 30 & 20.0 \\
\hline & Yearly twice/trice & 22 & 14.7 \\
\hline & Yearly once & 21 & 14.0 \\
\hline & Total & 150 & 100.0 \\
\hline \multirow[t]{5}{*}{$\begin{array}{l}\text { Awareness of Mobile } \\
\text { Banking }\end{array}$} & $\begin{array}{l}\text { Advertisement through } \\
\text { media }\end{array}$ & 33 & 22.0 \\
\hline & $\begin{array}{l}\text { Advertisement } \\
\text { newspaper/banners }\end{array}$ & 58 & 38.7 \\
\hline & Relatives and friends & 31 & 20.7 \\
\hline & Others & 28 & 18.7 \\
\hline & Total & 150 & 100.0 \\
\hline
\end{tabular}


International Journal of Trend in Scientific Research and Development (IJTSRD) ISSN: 2456-6470

\begin{tabular}{|l|l|l|l|}
\hline \multirow{3}{*}{$\begin{array}{l}\text { Knowledge of Manking } \\
\text { Bobile }\end{array}$} & Sufficient knowledge & 28 & 18.7 \\
\cline { 2 - 4 } & Average knowledge & 98 & 65.3 \\
\cline { 2 - 4 } $\begin{array}{l}\text { Satisfaction of Mobile } \\
\text { Banking }\end{array}$ & Tootal & 24 & 16.0 \\
\cline { 2 - 4 } & Highly satisfied & 150 & 100.0 \\
\cline { 2 - 4 } & Satisfied & 13 & 8.7 \\
\cline { 2 - 4 } & Neutral & 36 & 24.0 \\
\cline { 2 - 4 } & Dissatisfied & 47 & 31.3 \\
\cline { 2 - 4 } & Highly dissatisfied & 30 & 20.0 \\
\cline { 2 - 4 } & Total & 24 & 16.0 \\
\hline
\end{tabular}

Found that the 66.7 percent of the respondents are gender of male, 33.3percent of the respondents are gender of female. It is found that the majority of the respondents are gender of female.

$>$ Found that the 45.3 percent of the respondents are age of 25-35 years, 31.3 percent of the respondents are age of above 35 years and 23.3 percent of the respondents are age of below 25 . It is found that the majority of the respondents are age of 25-35 years.

Found that the 50.7 percent of the respondents are income group of 100000 to $300000,25.3$ percent of the respondents are income group of below 100000, 24 percent of the respondents are income group of above 300000 . It is found that the majority of the respondents are income group of 100000 to 300000 .

\section{CHI-SQUARE TEST}

\section{1) EDUCATIONAL QUALIFICATION AND PREFER MOBILE BANKING}

\section{NULL HYPOTHESIS (HO)}

There is no significant difference between Educational qualification and Prefer Mobile Banking

\section{ALTERNATIVE HYPOTHESIS (H1)}

There is a significant difference between Educational qualification and Prefer Mobile Banking.

\section{TABLE -II: RELATIONSHIP BETWEEN EDUCATIONAL QUALIFICATION AND PREFER MOBILE BANKING}

\begin{tabular}{|l|l|l|l|}
\hline Factors & Value & Df & $\begin{array}{l}\text { Asymp. Sig } \\
\text { (2-sided) }\end{array}$ \\
\hline Pearson chi- Square & 312.861 & 16 & .000 \\
\hline Likelihood Ratio & 249.154 & 16 & .000 \\
\hline Linear-by-linear association & 38.395 & 1 & .000 \\
\hline
\end{tabular}

\section{INFERENCE}

Since the 'p' value is less than 0.05 , the null hypothesis is rejected. So, there is a significant difference between Educational qualification and Prefer Mobile Banking.

\section{CONCLUSION}

Mobile Banking has become one of the important factor that has been effectively used by the consumer, based this the updations of Banks has to be done to retain and satisfy the customers. Mobile Banking updates the knowledge of the behavioral intention to adopt mobile with the usage for transfer of amount, funds, credit, debit, etc. Besides that, the findings of this study that will provide the knowledge of behaviour towards the mobile banking. Banks has to create certain programs to the customers regarding the dynamic change in the mobile banking process, which will make the customer to be satisfied with the service of banks. 


\section{REFERENCE}

1) A. Palani, P. Y. (2012). A Study On Customer Perception Towards Mobile Banking In Indian Overseas Bank Chennai. International Journal of Marketing and Technology , 2 (4), 262-276.

2) Amola bhatt, S. B. (2016). Factors Affecting Customer's Adoption of Mobile Banking Services. Journal of Internet Banking and Commerce , 21 (1), 1-22.

3) Chandran, R. (2014). Pros and cons of Mobile banking. International Journal of Scientific and Research Publications , 4 (10), 1-5.

4) Chuchuen, C. (2016). The Perception of Mobile Banking Adoption: The Study of Behavioral, Security, and Trust in Thailand. International Journal of Social Science and Humanity , 6 (7), 547-550.

5) D, A. (2016). A Study of Consumer Awareness towards e-Banking. International Journal of Economics \& Management Sciences , 5 (4), 1-4.

6) Darmesh Krishanan, A. A. (2015). Attitude towards Using Mobile Banking in Malaysia:A Conceptual Framework. British Journal of Economics, Management \& Trade , 7 (4), 306315.

7) Etim, A. S. (2014). Mobile banking and mobile money adoption for financial inclusion. Research in Business and Economics Journal , 9, 1-13.

8) Kaur, N. S. ( 2016). M-Services in India: A Study on Mobile banking and applications. Gian Jyoti EJournal , 6 (2), 45-52.

9) Masamila, B. ( 2014). State Of Mobile Banking In Tanzania Andsecurity Issues. International Journal of Network Security \& Its Applications (IJNSA), $6(4), 53-64$.

10) Mohammad Majedul Islam, M. E. (2004, MARCH). Consumers' Attitudes towards Mobile Banking in Bangladesh. Research gate .

11) Nitin nayak, V. N. ( 2014). A Study Of Adoption Behaviour Of Mobile Banking Services Byindian Consumers. Impact: International Journal of Research inEngineering \& Technology (IMPACT: IJRET) , 2 (3), 209-222.

12) Sharma, A. (2011). Mobile Banking As Technology Adoption And Challenges. International Journal of Multidisciplinary Research , 1 (6), 147-157.

13) YAO Huili, L. S. (2013). A Study of User Adoption Factors of Mobile Banking Services Based on theTrust and Distrust Perspective. International Business and Management , 6 (2), 914. 